\title{
Elimination of Vibrio Cholerae from Raw Sewage Using Chlorella Vulgaris: A Case of Chegutu Waste Reticulation, Zimbabwe
}

\author{
Hope Rukawo ${ }^{1}\left[\right.$ ] , Joe Phaeton Mukaro ${ }^{1 *}$ [ (])
}

${ }^{1}$ University of Zimbabwe, Department of Science Design and Technology Education, ZIMBABWE

*Corresponding Author: joe.mukaro@yahoo.co.uk

Citation: Rukawo, H. and Mukaro, J. P. (2022). Elimination of Vibrio Cholerae from Raw Sewage Using Chlorella Vulgaris: A Case of Chegutu Waste Reticulation, Zimbabwe. European Journal of Environment and Public Health, 6(1), em0104. https://doi.org/10.21601/ejeph/11724

\begin{tabular}{|c|c|}
\hline ARTICLE INFO & ABSTRACT \\
\hline Received: 6 Jul. 2021 & The research was aimed at eliminating Vibrio cholerae from raw sewage collected from home spills of Chegutu, \\
\hline Accepted: 3 Feb. 2022 & $\begin{array}{l}\text { Zimbabwe. An experimental approach was used in which homogenized raw sewage, inoculated with Chlorella } \\
\text { vulgaris culture was distributed equally into three tanks and left to stand for three weeks. Samples were extracted } \\
\text { from the three tanks and tested for the presence of Vibrio cholerae and physico-chemical parameters once in } \\
\text { seven days. Results showed a continuous decrease in the quantities of Vibrio cholerae as well as physico-chemical } \\
\text { parameters. Vibrio cholerae was totally eliminated from the sewage within } 21 \text { days. Chlorella vulgaris can be used } \\
\text { as a bioremediation agent to eliminate the Vibrio cholerae from sewage. The research recommends that the } \\
\text { prototype designed from this research could be used at a large scale in the elimination of Vibrio cholerae in } \\
\text { Municipal raw sewage. }\end{array}$ \\
\hline
\end{tabular}

Keywords: Vibrio cholerae, Chlorella vulgaris, bioremediation, wastewater, physico-chemical parameters

\section{INTRODUCTION}

Wastewater and sewage treatment is one of the obligatory services municipalities worldwide have to provide their residents with (Nathanson and Ambulkar, 2018). The wastewater and sewage have to be cleared of any contaminants, impurities and toxic substances before they can be discharged into water bodies that include rivers, dams and oceans, (Maliki et al., 2020). Many developing countries fail to efficiently treat wastewater because conventional plants are too technical and expensive in their construction and maintenance (Wang et al., 2014). These wastewater treatment plants also use expensive chemicals and require massive energy input (Sabuda et al., 2020).

Chegutu sewer pipes were laid more than 50 years ago catering for a smaller population $(15,000)$; however, the population has since ballooned to approximately over 60,000 to date hence the need for a more efficient sewage reticulation system (Chegutu Municipal Newsletter, 2018). The clogged old AC pipes compromise the flow of effluent to the sewer ponds so most residential areas are characterised by frequent bursts, creating a condition of cross-contamination of municipal water, and rendering the water unsafe to drink (Jena and Nyakudya, 2018). Figure 1 shows the sewage spills at one house in Chegutu town.

\section{Statement of the Problem}

In the aftermath of the 2008/9 massive cholera outbreak, the Ministry of Health and Child Care (MoHCC) engaged in various public awareness and health education programmes to conscientise the public on how the cholera bacterium is spread. Some minority groups seem to have not heeded the teachings as witnessed in the 2018 cholera outbreak localized to Chegutu following the passing of a female Moslem due to diabetes mellitus and diarrhoea that was characteristic of cholera (Nyamukondiwa, 2018). As per their tradition, a religious ritual to clean the deceased's intestines was performed. However, the relatives did not wear protective gloves leading to the death of two relatives soon after burial. The deceased exhibited symptoms that include vomiting and watery diarrhoea. The perilous cycle in infections and deaths prompted the MoHCC to intervene and treat it as any emergency (Nyamukondiwa, 2018).

Eleven years after the massive cholera outbreak that claimed 160 lives, sewage spills are still a common feature not only on roads but in residential yards. It is against this background that this research seeks to design a prototype for the elimination of Vibrio cholerae from sewage using the microalgae, Chlorella Vulgaris. Phytoremediation is a form of bioremediation that makes use of algae, naturally occurring microorganisms to remove pollutants from different types of wastewater (Sharma and Khan, 2013). Microorganisms that have the capability to degrade contaminants by employing 


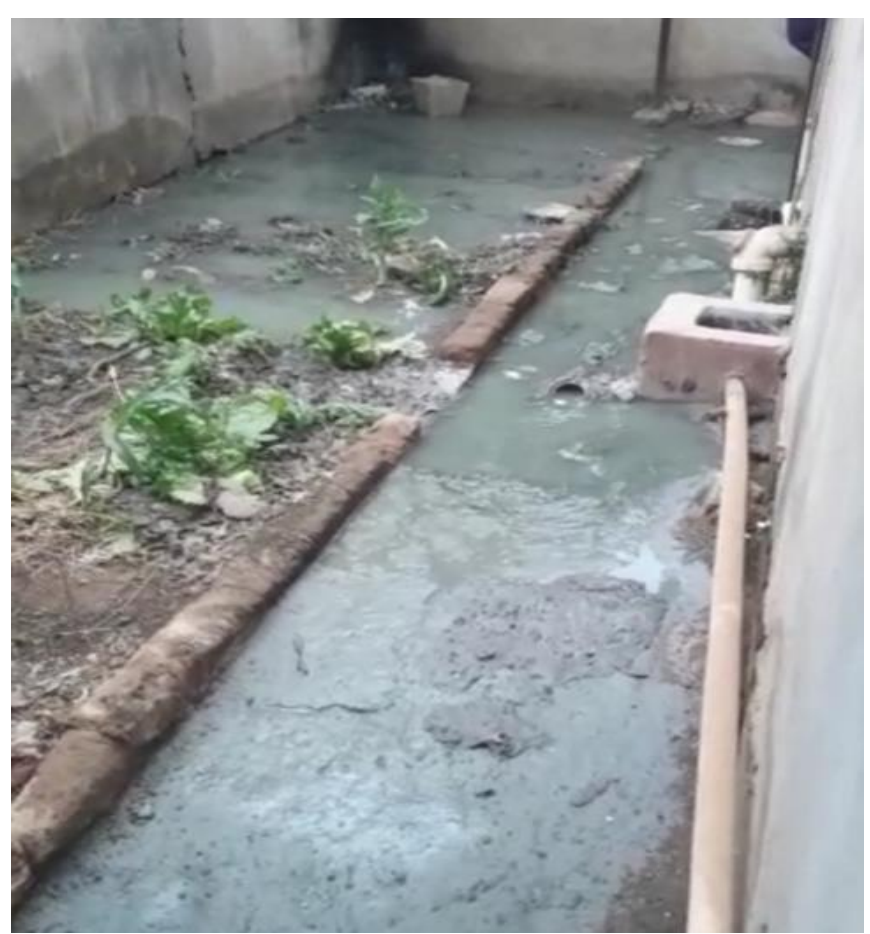

Figure 1. Sewage spills at one house in Chegutu town

metabolic degradation pathways are selected for different bioremediation approaches. In situ, bioremediation methods are preferred to ex-situ because they conserve the natural environment (Kumar and Kundu, 2020). Microorganisms are economical, effective and non-disruptive tools for transforming hazardous waste into less hazardous substances (Kumar et al., 2013).

\section{Objectives}

1. Determine the presence of Vibrio cholerae in raw sewage spills prominent in Chegutu residential area.

2. Determine methods for elimination of Vibrio cholerae in sewage spills.

3. Design a prototype for elimination of Vibrio cholerae from sewage spills.

\section{LITERATURE REVIEW}

Contained in domestic sewage are arrays of microorganisms that include bacteria, fungi, viruses, and some pathogenic nematodes that originate from soil and sanitary waste (Toze, 1997). Microorganisms present include Salmonella typhi, Vibrio cholerae, Shigella dysenteriae, Pseudomonas aeruginosa, and Streptococcus aureus. They are discharged by persons infected with intestinal diseases such as cholera, typhoid, fever, dysentery and shigellosis (Dumontet et al., 2001).

Sewage treatment is the process of annihilating contaminants, toxins and pollutants from sewage or wastewater so that it can be safely disposed and reintroduced back into the natural environment (Basika et al., 2020). Studies done in South Africa by Okeyo et al. (2018) show that a significant number of wastewater treatment plants release semi-treated effluent that contain pathogens that include
Vibrios. It is imperative that the quality of wastewater effluent is monitored because globally, $80 \%$ flows back into the environment (Osunla and Okoh, 2017). The products of sewage treatment are mostly used by humans for various beneficial purposes (Garcha et al., 2016). The liquid effluent may be released into water bodies that include seas, lakes, dames, and rivers or may be used for agrarian purposes while the semisolid sewage sludge may be used as fertilizers. It is therefore important that the wastewater be treated efficiently so that the environment is not harmed by the different microorganisms found in sewage and wastewater (Prasad et al., 2019).

Dasgupta et al. (2019) explain that sewage wastewater treatment is important in reducing the biological oxygen demand (BOD), salinity, chemical oxygen demand (COD), phosphates, nitrates, and heavy metals. These emanate from detergents, softeners, bath soaps, shampoos, and run offs from agriculture. All these reduce the quality of water to levels that are unfit for use and human consumption (Zhao et al., 2016).

Treatment of wastewater is therefore important to reduce pathogens to acceptable levels that do not affect humans, fauna and flora. Treatment methods should aim to destroy most toxigenic pathogens to curb recontamination and remove nutrients such as nitrates and phosphates so that the pathogens will not regrow. Kumar et al. (2013) reiterate that sewage or wastewater effluent may percolate into the ground water resulting in contamination of drinking water. Inefficient treatment therefore may translate to humans and animals being indirectly exposed to toxigenic pathogens that include S. typhimuriam (Sharma and Khan, 2013).

Demirbas et al. (2017) posit that the nitrates and phosphates in sewage and sewage effluent stimulate growth of aquatic plants and algae which are fed upon by fish. Nongogo and Okoh (2014) further reiterate that elevated nitrates and phosphates further cause increases in fish population which will subsequently impact negatively on the ecological balance. The effects of nitrates in aquatic bodies have been well explained by Salgueiro et al. (2016) who further explain that nitrates may also cause algal bloom which in turn causes oxygen depletion in water bodies; thus, resulting in deaths of aquatic organisms. The abundant nitrates and the phosphates may also cause increased growth of aquatic bacterial populations (Wang et al., 2010). The final effluent may even alter the $\mathrm{pH}$ of the receptacle water bodies. These fluctuations in water $\mathrm{pH}$ may affect the breeding patterns of the different aquatic organisms. Increases in water $\mathrm{pH}$ may also cause bleaching of coral reefs (Olguín, 2003).

Studies have discovered that a number of Vibrio species are abundant in effluent from wastewater treatment plants from Sub-Saharan Africa (UNICEF, 2018). Some Vibrio species of great medical importance include Vibrio vulnifcus, Vibrio parahaemolyticus, Vibrio mimicus, and Vibrio cholerae. All these are toxigenic and are transmitted through contaminated water and food causing serious diseases (Osunla and Okoh, 2017).

Vibrio cholerae are curved, gram negative bacilli and facultative anaerobes that are capable of carrying out both respiration and fermentation (Nongogo and Okoh, 2014). The bacterium is $1-3$ micrometres by $0.5-0.8$ micrometres and belongs to the Vibrionaceae family. It is very motile with a single sheathed polar flagellum (Robinson, 2014). A study 
carried out by Huq et al. (2005) conclude that Vibrio cholerae are autochthonous to aquatic environments where they thrive on aquatic plant reservoirs that include Eichhornia crassipes and aquatic organisms such as crustaceans.

Studies by Bharati and Ganguly (2011) have revealed that toxigenic variants of Vibrio cholerae, serogroup 01 and 1039 are the etiological agents of cholera, a gastrointestinal disorder that is characterized by watery diarrhoea, abdominal pains and vomiting. All these symptoms collectively result in severe dehydration that might lead to death. Winstead etal. (2020) explain that the bacteria release an adenosine diphosphateribosylating enzyme called the cholera toxin (CT). Bharati and Ganguly (2011) further explain that the CT is the principal virulence factor which increases the pumping out of sodium and chloride ions into the lumen of the small intestines resulting in osmotic imbalance which causes elimination of large volumes of water from the epithelial cells of the small intestines.

Cholera is a grave public health problem in Africa with persistent endemicity as shown by statistics from (World Health Organisation, 2018). Suspected cholera cases reported to WHO by African countries between 1970 and 2014 were 3 221050 . This figure constitutes $46 \%$ of all global cases and $56 \%$ of these infections were from sub-Saharan Africa (Mengel et al., 2014). Although the most notable cause of cholera and other water borne diseases is contamination of food and drinking water with faecal matter, a number of other factors have also come into play (Cartwright et al., 2013). These include poverty and overcrowding due to natural disasters that force people to stay in refugee camps, political or economic crises, poor sanitation, insufficient health education and ailing economies (Mulamattathil et al., 2014).

Naturally, microorganisms degrade environmental contaminants that are introduced into the environment through natural and anthropogenic processes (Mora-Ravelo et al., 2017). Metabolism of the organic compounds by the microorganisms results in the production of carbon dioxide, methane, water and biomass. The carbon dioxide is used for cell growth and reproduction (Kumar et al., 2013). Salgueiro (2016) explain that the microbes can employ enzymes to transform the contaminants into compounds that are less toxic or harmful to the environment. Bioremediation therefore can be explained as the catabolic potential of a microorganism to degrade pollutants by using them as a source of energy or food resulting in restoration of ecological balance (MoraRavelo et al., 2017). Although bioremediation relies on native microbial species, techniques can be employed to enhance the biodegradation potential of the microorganisms. Different microbial species with known degrading abilities could be imported to augment the native species to enhance the degradation process or nutrients and other physical and chemical parameters that promote microbial growth could be added and or adjusted to quantities that will speed up the degradation process (Salgueiro et al., 2016).

Advantages of bioremediation have been explicitly explained by Mora-Ravelo et al. (2017) as being very easy to implement and environmentally friendly because pollutants can be degraded in-situ without disturbing the environment. After the contaminants are changed into innocuous metabolites, the site can continue to be used. In-situ treatment of contaminants also reduces the risk associated with transportation accidents. The process is more economical compared to conventional methods such as incineration (Mora-Ravelo et al., 2017). However, other researchers that include Sharma and Khan (2013) contend that bioremediation is a slow process that may require close monitoring as contaminants may fail to be reduced to globally acceptable levels. Wang et al. (2010) further contend that although enhancement increases microbial degrading abilities, the substances introduced to enhance the bioremediation process may further cause contamination problems.

Previous studies by Olguín (2003), Sharma and Khan (2013), and Wang et al. (2010) have concluded that bioremediation is dependent upon two factors:

1. the degradability of the contaminant and

2. the site of contamination.

Microorganisms used to detoxify substances that could pose as a danger to man and his surroundings include bacteria, fungi and algae. The use of microalgae to remove pollutants from different environments is known as phycoremediation (Pilon-Smits, 2005).

Chlorella vulgaris is a eukaryotic, unicellular, and photosynthetic microorganisms naturally abundant in aquatic systems that include seawater and freshwater. The microalga has been extensively researched on due to its various and unique properties (Ferreira and Gouveia, 2020). Gonçalves et al. (2017) describe the microalga as versatile with proven efficiencies in nutrition, cosmetics, pharmaceuticals, health, and wastewater bioremediation. Ferreira and Gouveia (2020) further explain that Chlorella vulgaris is capable of converting solar energy and carbon dioxide into biomass which in turn can be transformed into diverse marketable products that include food supplements, health supplements, aqua feed, poultry feed, bioacetone, biomethane and biofuel.

Chlorella vulgaris has been employed as a bioremediation agent in different types of wastewater because of its dual purpose of removing pollutants and generating biomass (Sharma and Khan, 2013). Some researchers that have extensively researched on $C$. vulgaris that include Zhao et al. (2016) have concluded that $C$. vulgaris is the best microalga to use for the removal of ammonium in wastewater because it does not generate ammonia, a secondary pollutant. In a study carried out by Taziki et al. (2015), it was revealed that the microalgae were able to remove nitrates and nitrites from wastewater by assimilation. In Zimbabwe, Sero et al. (2021) isolated and selected four microalgae native to Zimbabwe with potential use in biodiesel production. These were Chlorella $s p p$, Oscillatoria spp. Scenedemus spp and Microcystis spp. The study revealed that $C$. vulgaris had high growth and lipid production rate.

Microalgae, in general and Chlorella vulgaris in general have been used in conjunction with other microorganisms such as bacteria and fungi (Ru et al., 2020). In an experimental investigation to evaluate the performance of Chlorella vulgaris and Enterobacter sp MN17 to remove organic carbon, heavy metals and colour in wastewater from the textile industry, Mubashar et al. (2020) noted that removal efficiency of $C$. vulgaris increased with addition of an Enterobacter $s p$ inoculum. The bacterial inoculation stimulated proliferation 
of the microalgal biomass due to the growth promoting characteristics of the Enterobacter $s p$. Bacteria-algae interactions in aquatic ecosystems studied by Cole (2003) showed that bacteria may stimulate algal growth by regeneration of nutrients and production of essential vitamins while algae are capable of promoting bacteria growth by decomposition of organic matter and subsequent release of nutrients.

\section{MATERIALS AND METHODS}

The research adopted a quantitative paradigm that was mainly characterized by experimental work. Quantitative research employs the scientific method to systematically investigate and examine the cause-effect relationship by manipulation and controlling of variables. It involves the collection and statistical analysis of numerical data to test hypothesis (Bloomfield and Fisher, 2019; Goertzen, 2017).

Quantitative data was collected by measuring physicochemical parameters. Untreated raw sewage was collected in a 5-litre sterilized polypropylene bottle to reduce the chances of contamination and possible deterioration. A 2-litre plastic bottle was improvised as a collecting cup by cutting it in half using a surgical blade. The collecting cup was sterilized by washing with hypochlorite and was used to scoop the raw sewage from the ground. Samples were preserved in ice boxes at temperatures around $10^{\circ} \mathrm{C}-15^{\circ} \mathrm{C}$ within 24 hours. Such ambient temperatures enhance culturability of the microorganism (Sirisha et al., 2017). WHO (2019) states that $V$. cholerae is a biosafety level 2 (BSL-2) pathogen therefore appropriate guidelines for the use and handling of dangerous microorganism were followed.

\section{Data Presentation and Analysis}

Data was presented in form of tables showing the growth of Vibrio cholerae colonies and various physico-chemical parameters. Physical and chemical parameters that include $\mathrm{pH}$, temperature, salinity, dissolved oxygen, conductivity, turbidity, total suspended solids, total dissolved solids, nitrates, phosphates, chemical oxygen demand and biological oxygen demand were measured immediately upon reaching the laboratory because they affect Vibrio cholerae densities (Sharma and Khan, 2013). Prescribed standard laboratory procedures were used to measure different parameters. This ensured validity and reliability of the data.

Physico-chemical parameters were measured in triplicate on the first day and after every 7 days for 3 consecutive weeks. Weekly, $1 \mathrm{ml}$ of sewage was also withdrawn from tanks 1,2 , and 3 and subsequently plated onto plates labelled 1,2 , and 3 . Colony forming units were also counted from each plate after 24 hours of incubation at $37^{\circ} \mathrm{C}$.

\section{Chlorella Vulgaris Culture}

The green microalgae strain, Chlorella vulgaris, was obtained from University of Zimbabwe, Department of Biological Sciences as a pure culture. The pure culture was grown in Bolds Basal Medium and exposed to light for 5 days to allow the algae to grow. The medium comprised of the following:

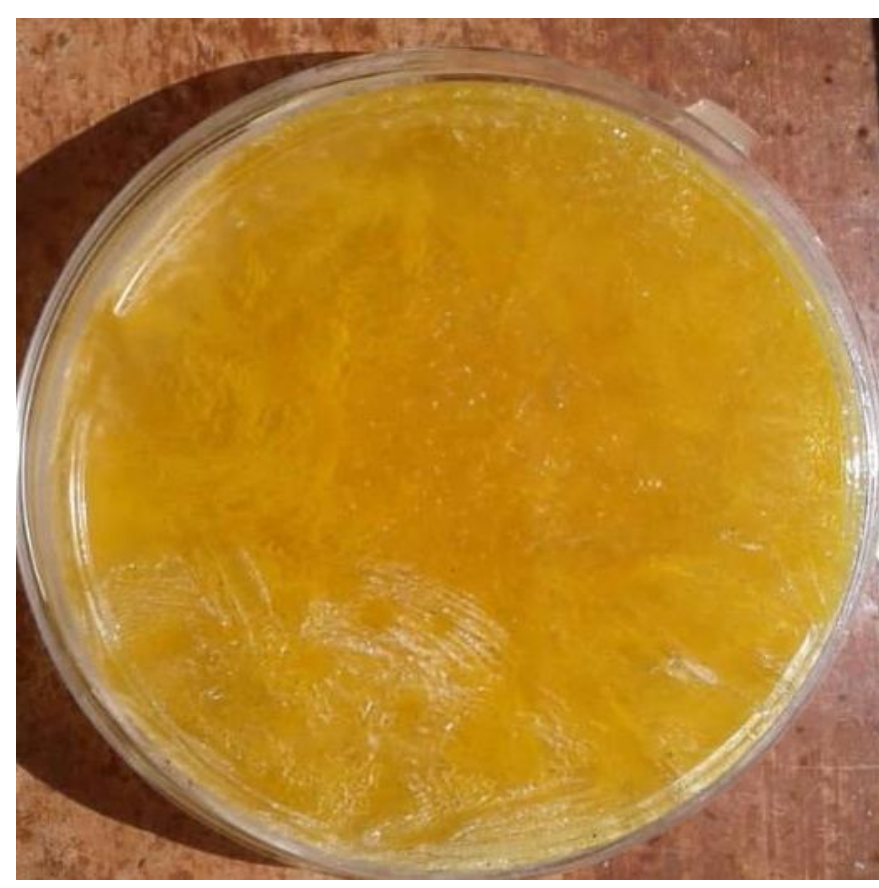

Figure 2. Plate 1-Vibrio cholerae colonies developing

$\begin{array}{ll}\mathrm{NaNO}_{3} & 10 \mathrm{~g} \\ \mathrm{CaCl}_{2} .2 \mathrm{H}_{2} \mathrm{O} & 1 \mathrm{~g} \\ \mathrm{MgSO}_{4} .7 \mathrm{H}_{2} \mathrm{O} & 3 \mathrm{~g} \\ \mathrm{~K}_{2} \mathrm{HPO}_{4} & 3 \mathrm{~g} \\ \mathrm{NaCl} & 1 \mathrm{~g}\end{array}$

Three erlenmeyer 5-litre containers were filled with $1,000 \mathrm{ml}$ of sewage water each and labelled tank 1,2 , and 3 . $100 \mathrm{ml}$ of $C$. vulgaris culture were later withdrawn and inoculated into each of the three tanks. The 3 tanks were exposed to sunlight during daytime while an external light source, $2 \times 3 \mathrm{~W}$ fluorescent lamp was availed during the night. Tank tops were covered with aluminium foil to reduce contamination.

\section{RESULTS AND DISCUSSION}

TCBS agar plates observed for the presence and identification of Vibrio cholerae in sewage showed convincing round, smooth, and slightly flattened yellow colonies that were rather too numerous to be counted. This showed that Vibrio cholerae was present in the sewage from Chegutu town. Figure 2 depicts Vibrio cholerae colonies developing.

Tests done by other researchers that include Shaffer et al. (1989) explain that colonies of Vibrio cholerae grown on TCBS agar are observed as large $(2-4 \mathrm{~mm})$, smooth, round, and glistening yellow colonies. At the beginning of the experiment, the agar is blue in colour. Okeyo et al. (2018) explain that this transition from blue to yellow is as a result of sucrose fermentation which increases acidicty. It is the acidicity which makes the Bromthymol blue, a pH indicator in the medium to turn yellow. The increased $\mathrm{pH}$ supports Vibrio cholerae growth (Baron et al., 2017). These results from other studies therefore confirm the colonies in plate 1 in Figure 2 are Vibrio cholerae colonies. 
Table 1. Parametric measurements at the beginning

\begin{tabular}{lc}
\hline Parameter & Reading \\
\hline pH & 7.894 \\
\hline Conductivity (Us/cm) & 1,250 \\
\hline TDS $(\mathrm{mg} / \mathrm{L})$ & 728 \\
\hline Salinity $(\mathrm{ppt})$ & 0.5 \\
\hline DO $(\mathrm{mg} / \mathrm{L})$ & 2.23 \\
\hline Turbidity $(\mathrm{NTU})$ & 3,515 \\
\hline TSS $(\mathrm{mg} / \mathrm{L})$ & 2,150 \\
\hline COD $(\mathrm{mg} / \mathrm{L})$ & 426 \\
\hline BOD $(\mathrm{mg} / \mathrm{L})$ & 36 \\
\hline R/Phosphorus $(\mathrm{mg} / \mathrm{L})$ & 3.604 \\
\hline Nitrates $(\mathrm{mg} / \mathrm{L})$ & 0.062 \\
\hline
\end{tabular}

These observations were based on the initial physicochemical parameters as shown in Table 1.

The intial measurements of the chemical and physical parameters indicate that the sewage sample contained abundant organic and inorganic nutrients that could be attributed to the elevated Vibrio cholerae populations.

\section{Gelatin Agar Results}

Suspect isolates from the TCBS agar plates were grown on non-selective Gelatin agar and incubated overnight at $37^{\circ} \mathrm{C}$. Smooth, opaque, and white zones around the coloies were observed. This result is comparable with results from a study done in Eastern Meditteranean by Huq and Colwell (1996) who described opaque zone around the colonies as the halo effect.

\section{Gram Staining Results}

The Gram staining procedure differentiates bacteria according to their cell wall. Presumptive Vibrio cholerae isolates from the TCBS agar plates were stained as morphological confirmation. Vibrio cholerae cells appeared comma shaped and stained pink confirming that they are Gram negative which agrees with results by Sirisha et al. (2017). According to Osunla and Okoh (2017) the bacterial cells stain pink because their cell walls contain only $10 \%$ peptidoglycan and a greater percentage of lipids. The outer lipopolysaccharide layer is dissolved by the alcohol and they fail to retain the crystal violet colour.

\section{Oxidase Test Results}

Gram negative isolates were further selected for the oxidase test which was performed as described by Shields and Cathcart (2010). Colonies were picked with a sterile wooden applicator and streaked on a filter paper saturated with the oxidase reagent. A dark purple colour appeared in 7 seconds confirming that they were Vibrio cholerae isolates. This result agrees with observations from Shields and Cathcart (2010).

\section{Presentation and Discussion on Bioremediation of Vibrio Cholerae}

Results for the bioremediation were presented in two phases, firstly, the physico-chemical parameters and later, the Chlorella vulgaris culture effect.

\section{Results of the physico-chemical parameters}

Table 2 presents the results of the physico-chemical parameters recorded 7 days after inoculation of the sewage with Chlorella vulgaris. Measuring was done in triplicate, from
Table 2. Parametric measurements after 7 days

\begin{tabular}{lccccc}
\hline Parameter & Tank1 & Tank2 & Tank3 & Mean & $\begin{array}{c}\text { Change } \\
\text { (\%) }\end{array}$ \\
\hline Ph & 8.937 & 8.762 & 8.924 & 8.874 & \\
\hline Conductivity (us/cm) & 882 & 863 & 849 & 865 & 30.8 \\
\hline TDS (mg/L) & 521 & 562 & 549 & 544 & 25 \\
\hline Salinity (ppt) & 0.3 & 0.3 & 0.3 & 0.3 & 40 \\
\hline DO (mg/L) & 3.39 & 2.58 & 2.29 & 2.75 & 23.3 \\
\hline Turbidity (NTU) & 1,731 & 1,843 & 1,922 & 1,832 & 47.9 \\
\hline TSS (mg/L) & 951 & 900 & 1053 & 968 & 55 \\
\hline COD (mg/L) & 390 & 380 & 431 & 398 & 6.9 \\
\hline BOD (mg/L) & 389 & 399 & 399 & & \\
\hline R/Phos (mg/L) & 32 & 29 & 28 & 29.7 & 16.7 \\
\hline Nitrates (mg/L) & 3.161 & 3.413 & 3.408 & 3.279 & 9 \\
\hline
\end{tabular}

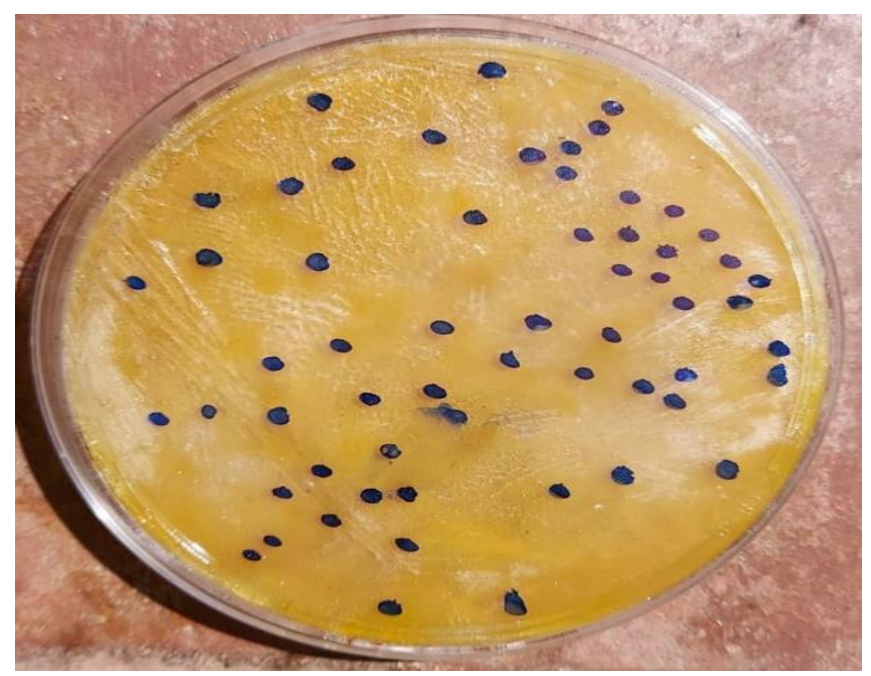

Figure 3. Plate $2-V$. cholerae colonies 7 days after culturing the sewage with $C$. vulgaris

the 3 Elernmeyer flasks termed tanks in the table of measurements. Measurement in triplicate was done to ensure validity and reliability.

The first 7 days were characterized by significant changes in the physical and chemical parameter measurements. There was a notable increase in $\mathrm{pH}$ and DO. $\mathrm{pH}$ increased from 7.894 as shown in Table 1 to an average of 8.874 (Table 2) while DO increased by $23.3 \%$ from 2.23 to $2.75 \mathrm{mg} / \mathrm{L}$. However, all the other parameters recorded significant decreases. Conductivity recorded a $30.8 \%$ decrease from $1250 \mathrm{us} / \mathrm{cm}$ to an average of $865 \mathrm{us} / \mathrm{cm}$ while TDS decreased by $25 \%$ from $728 \mathrm{mg} / \mathrm{L}$ to an average of $544 \mathrm{mg} / \mathrm{L}$. Least decreases were recorded in COD, reactive orthophosphorus and BOD which decreased by $6.9 \%$, $9 \%$, and $16.7 \%$, respectively. TSS showed the greatest decrease of $55 \%$ followed with turbidity, nitrates and salinity that decreased by $47.9 \%, 45 \%$, and $40 \%$, respectively.

Plate 2 in Figure 3 shows the number of CFUs that had grown on TCBS agar after plating with sewage wastewater 7 days after inoculating it with Chlorella vulgaris. Although the CFUs were still numerous, they could be counted with no dificulty using a Gallenkamp colony counter.

Measurements taken on the 14th day of the experiment (Table 3) showed increases in $\mathrm{pH}$ and DO. pH further increased 
Table 3. Parametric measurements after 14 days

\begin{tabular}{|c|c|c|c|c|c|}
\hline Parameter & Tank1 & Tank2 & Tank3 & Mean & $\begin{array}{c}\text { Change } \\
\text { (\%) }\end{array}$ \\
\hline $\mathrm{Ph}$ & 9.910 & 9.813 & 9.752 & 9.825 & \\
\hline Conductivity (us/cm) & 600 & 637 & 629 & 622 & 28 \\
\hline TDS (mg/L) & 364 & 384 & 384 & 377 & 30.7 \\
\hline Salinity (ppt) & 0.1 & 0.1 & 0.1 & 0.1 & 40 \\
\hline $\mathrm{DO}(\mathrm{mg} / \mathrm{L})$ & 5.3 & 5.7 & 5.2 & 5.4 & 49.1 \\
\hline Turbidity (NTU) & 1,530 & 1,639 & 1,701 & 1,623 & 11.4 \\
\hline TSS (mg/L) & 940 & 888 & 1,011 & 946.3 & 2.3 \\
\hline \multirow{2}{*}{$\mathrm{COD}(\mathrm{mg} / \mathrm{L})$} & 351 & 331 & 371 & \multirow{2}{*}{363} & \multirow{2}{*}{11} \\
\hline & 359 & 345 & 355 & & \\
\hline $\mathrm{BOD}(\mathrm{mg} / \mathrm{L})$ & 24 & 21 & 21 & 22 & 26.7 \\
\hline \multirow{2}{*}{ R/Phos (mg/L) } & 1.318 & 1.421 & 1.444 & \multirow{2}{*}{1.439} & \multirow{2}{*}{56} \\
\hline & 1.516 & 1.440 & 1.493 & & \\
\hline \multirow{2}{*}{ Nitrates (mg/L) } & 0.031 & 0.023 & 0.023 & \multirow{2}{*}{0.025} & \multirow{2}{*}{26.5} \\
\hline & 0.029 & 0.019 & 0.022 & & \\
\hline
\end{tabular}

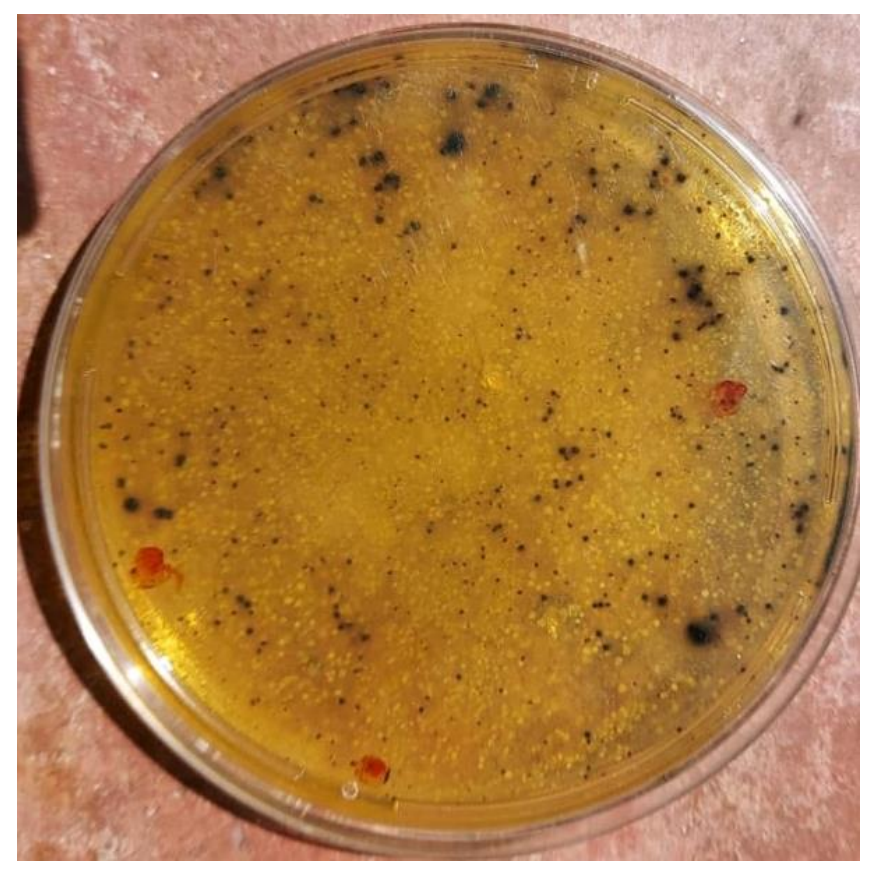

Figure 4. Plate $3-V$. Cholerae colonies 14 days after culturing the sewage with $C$. vulgaris

to 9.825 from 8.874 while DO increased by $49.1 \%$ to $5.4 \mathrm{mg} / \mathrm{L}$. All the other parameters recorded steady decreases with the least in TSS, turbidity, and COD which decreased by $2.3 \%$, $11.4 \%$, and $11.6 \%$, respectively. Nitrates, BOD, and conductivity decreased by more than $25 \%$ while salinity and phosphates decreased the most by $40 \%$ and $56 \%$, respectively.

There was not much growth observed in the TCBS agar plates 14 days into the experiment (Figure 4). Only three colonies (in red ink) were observed in one plate while the other two plates exhibited no sign of growth. The decline in bacterial population could be attributed to the depletion of essential and key nutrients in the sewage.

All the parameters including $\mathrm{pH}$ and $\mathrm{DO}$ that had previously been inceasing showed moderate decrease in the third week (Table 4). DO decreased by $33 \%$ to 3.6 from 5.4 $\mathrm{mg} / \mathrm{L}$ while $\mathrm{pH}$ decreased to an average of 8.525 from 9.825 . Salts were totally depleted as zero ppt was recorded. Conductivity, TDS, turbidity, TSS, BOD, COD, and reactive
Table 4. Parametric measurements after 21 days

\begin{tabular}{lccccc}
\hline Parameter & Tank1 & Tank2 & Tank3 & Mean & $\begin{array}{c}\text { Change } \\
\text { (\%) }\end{array}$ \\
\hline Ph & 8.485 & 8.606 & 8.491 & 8.527 & \\
\hline Conductivity (us/cm) & 520 & 566 & 417 & 501 & 19 \\
\hline TDS (mg/L) & 331 & 345 & 291 & 322 & 14.6 \\
\hline Salinity (ppt) & 0 & 0 & 0 & 0 & 20 \\
\hline DO (mg/L) & 3.3 & 3.7 & 3.9 & 3.6 & 33 \\
\hline Turbidity (NTU) & 1,329 & 1,403 & 1,433 & 1,388 & 14.8 \\
\hline TSS (mg/L) & 733 & 721 & 825 & 760 & 19.3 \\
\hline COD (mg/L) & 351 & 276 & 172 & 269 & 18 \\
\hline BOD (mg/L) & 359 & 287 & 171 & & \\
\hline R/Phos (mg/L) & 24 & 21 & 21 & 22 & 17.4 \\
\hline Nitrates (mg/L) & 1.318 & 1.421 & 1.444 & 1.439 & 17.3 \\
\hline
\end{tabular}

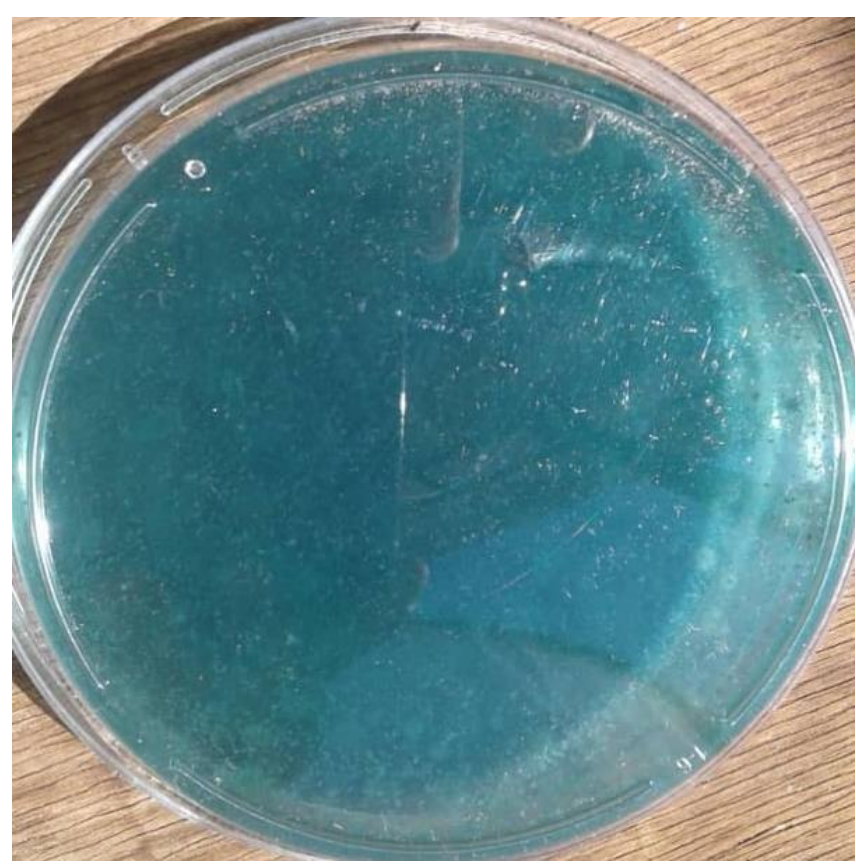

Figure 5. Plate 4-V.cholerae colonies 21 days after culturing the sewage with $C$. vulgaris

orthophosphorus decreases were below $20 \%$. Nitrates had the greatest decrease of $39.4 \%$ to $0.020 \mathrm{mg} / \mathrm{L}$ from $0.025 \mathrm{mg} / \mathrm{L}$.

The TCBS agar plates exhibited no sign of growth as evidenced by the colour of the plates (Figure 5). There was no sucrose fermentation and therefore no change in $\mathrm{pH}$, hence, the Bromothymol blue, a $\mathrm{pH}$ indicator maintained the blue colour. This result shows that the Vibrio cholerae in sewage had been totally eliminated.

Table 5 shows weekly average measurements of parameters. Similarly, Table 6 depicts average CFUs. An average of 506 CFUs were counted in each plate as shown in Table 6.

Results from this study have shown that Vibrio cholerae was eliminated completely within 21 days of treatment due to the influence of Chlorella vulgaris. Maximum reduction in the $V$. cholerae was achieved within the first 7 days of the treatment. Zhao et al. (2016) affirm that $C$. vulgaris is an important player in the management of water resources. Its fast growth rate coupled with the very high proliferation rate has made it the 
Table 5. Weekly average measurements of parameters

\begin{tabular}{lccccc}
\hline Parameter & $\begin{array}{c}\text { Initial } \\
\text { reading }\end{array}$ & Week1 & Week2 & Week3 & $\begin{array}{c}\text { Change } \\
\text { (\%) }\end{array}$ \\
\hline Ph & 7.894 & 8.874 & 9.825 & 8.522 & \\
\hline Conductivity (us/cm) & 1,250 & 865 & 622 & 501 & $59.9 \%$ \\
\hline TDS $(\mathrm{mg} / \mathrm{L})$ & 728 & 544 & 377 & 322 & $55.8 \%$ \\
\hline Salinity $(\mathrm{ppt})$ & 0.5 & 0.3 & 0.1 & 0 & $100 \%$ \\
\hline DO $(\mathrm{mg} / \mathrm{L})$ & 2.23 & 2.75 & 5.4 & 3.6 & $100 \%$ \\
\hline Turbidity $(\mathrm{NTU})$ & 3,515 & 1,832 & 1,623 & 1,383 & $60.7 \%$ \\
\hline TSS $(\mathrm{mg} / \mathrm{L})$ & 2,150 & 968 & 946 & 763 & $64.5 \%$ \\
\hline COD $(\mathrm{mg} / \mathrm{L})$ & 426 & 398 & 352 & 213 & $50 \%$ \\
\hline BOD $(\mathrm{mg} / \mathrm{L})$ & 36 & 29.6 & 22 & 18 & $50 \%$ \\
\hline R/Phos $(\mathrm{mg} / \mathrm{L})$ & 3.604 & 3.279 & 1.439 & 1.189 & $67 \%$ \\
\hline Nitrates $(\mathrm{mg} / \mathrm{L})$ & 0.062 & 0.034 & 0.025 & 0.020 & $67.7 \%$ \\
\hline & & & & &
\end{tabular}

Table 6. Average CFUs

\begin{tabular}{|c|c|c|c|c|}
\hline \multirow{2}{*}{ Time/days } & \multicolumn{3}{|c|}{ Colony forming units } & \multirow{2}{*}{$\begin{array}{c}\text { Average } \\
\text { CFUs/plate }\end{array}$} \\
\hline & Tank 1 & Tank 2 & Tank 3 & \\
\hline 0 days & TNTC & TNTC & TNTC & TNTC \\
\hline 7 days & 570 & 470 & 480 & 506 \\
\hline 14 days & 3 & 0 & 0 & 1 \\
\hline 21 days & 0 & 0 & 0 & 0 \\
\hline
\end{tabular}

microalgae of choice by many in wastewater treatment and pollutant removal.

Results from this study showed that the $\mathrm{pH}$ of the sewage water became more alkaline increasing from 7.894 to 9.825 then slightly decreased to 8.525 . This result correlates with results from other phycoremediation studies done elsewhere. Studies by Wang et al. (2010) on phycoremediation of wastewater using of $C$. vulgaris concluded that the microalgae experience maximum growth in the $\mathrm{pH}$ of range 6.0-9.0. Zhao et al. (2010) who carried out a similar study in China explained this increase in $\mathrm{pH}$ as a result of a shift in chemical equilibrium by the $C$ vulgaris. This occurs when carbon dioxide combines with water resulting in the formation of carbonic acid. The carbonic acid later disintegrates into a carbonate and a hydroxyl group. It is therefore the increase in carbonate concentration coupled with the decrease in carbonic acid that increases the $\mathrm{pH}$ of the sewage water. Chiu et al. (2015) explain the increase in $\mathrm{pH}$ as being caused by the degradation of organic compounds by $C$. vulgaris.

Reactive orthophosphorus decreased by $67 \%$ from the initial $3.604 \mathrm{mg} / \mathrm{L}$ to $1.180 \mathrm{mg} / \mathrm{L}$ during the study period. In other studies, done by Wang et al. (2010), C vulgaris was able to remove $97 \%$ of the phosphorus from wastewater. In another study by Salgueiro et al. (2016), C. vulgaris removed 99.2\% phosphorus from synthetic wastewater. The microalga assimilates the phosphorus into its cells and use it to synthesize different components of the cells that include phospholipids, Adenosine triphosphate (ATP) and nucleic acids. The element is also believed to be important in cell division (Zhao et al., 2016). Studies by Mohammed et al. (2014) have also revealed that microalgae in general and $C$. vulgaris in particular can employ the "luxury uptake" mechanism to assimilate and store phosphorus. Chlorella vulgaris have high phosphorus removal efficiency because they have high sequestration potential therefore they can sequestrate the element from the phosphates in the sewage and use them for growth and biomass accumulation (Dasgupta et al., 2019).
Study by Xin et al. (2010) concluded that the concentration of phosphorus in wastewater is directly proportional to $C$. vulgaris' growth.

Nitrates were reduced by $67.7 \%$ from the initial $0.062 \mathrm{mg} / \mathrm{L}$ to $0.020 \mathrm{mg} / \mathrm{L}$. Shahid et al. (2020) posit that just as in phosphates, Chlorella vulgaris assimilate nitrogen into their cells and use them as nutrients resulting in growth and increase in biomass. Gonçalves et al. (2017) explain that nitrates are actively taken into the algal cells via the cell surface membrane. In an experimental study by Kumar et al. (2013) to test the nitrate removal efficiency of $C$. vulgaris from aqueous solutions, the microalgae removed $88 \%$ of the nitrates. In another study by Otondo et al. (2018), Chlorella vulgaris achieved a $70.3 \%$ nitrate removal. The $67.7 \%$ nitrate removal achieved in this study is therefore coincident with results from other researches. However, in other studies, $C$. vulgaris achieved more than $90 \%$ nitrogen removal. A study by Sharma and Khan (2013) on bioremediation of sewage wastewater using selective algal species, $C$ vulgaris achieved a $90 \%$ nitrate removal. This figure is however not in sync with findings from the current study. This could have been caused by the elevated $\mathrm{pH}$ which affects nitrate assimilation. SegoviaBifarini et al. (2020) explain that ammonium is a form of nitrogen preferred by microalgae because very little energy is used in ammonium assimilation as compared to nitrates. However, in $\mathrm{pH}$ above 8, the ammonium disintegrates to form ammonia, a form of nitrogen toxic to microalgae. In this study, $\mathrm{pH}$ increased to 9.825 so it can be inferred that the $C$. vulgaris could not efficiently assimilate the nitrogen and phosphorus due to ammonia toxicity (Kumar and Kundu, 2020).

A study by Wirth et al. (2020) revealed that both nitrates and phosphates consumption in wastewater largely depends on how easily light can penetrate. Turbidity, TSS TDS therefore affects removal of these inorganic compounds. The slight decrease of $9 \%$ in phosphorus during the first 7 days of the experiment could be attributed to the high turbidity. Initial turbidity reading was $3,515 \mathrm{NTU}$ which decreased by almost $48 \%$ in the first week to 1,832 NTU. This sharp decrease in turbidity also resulted in a sharp decrease of $56 \%$ in phosphorus in the following week. These results strongly correlate with conclusions from the above study by Wirth et al. (2020). TSS and TDS were reduced by $64.5 \%$ and $55.8 \%$ respectively in the current study. The decrease in the suspended and dissolved solids could be explained as a result of the $C$. vulgaris sequestration efficiency. The total dissolved and suspended solids are nutrient rich therefore they are taken in by the microalgae for growth (Gonçalves et al., 2017). Studies by Sharma and Khan (2013) using different microalgal strains that included Chlorella minutissima, Scenedemus spp, and Chlorella vulgaris showed an 90\% average T, A. LDS removal by all the microalgal strains. TSS value is generally increased by the presence of organic and inorganic matter in sewage (Wang et al., 2010). The $64.5 \%$ reduction was therefore as a result of utilization of the organic and inorganic compounds (Segovia-Bifarini et al., 2020). In another study by Kumar et al. (2013), Chlorella vulgaris reduced TDS by $97.5 \%$. The slightly lower TSS and TDS removal efficiencies exhibited in this study are not comparable with results from previous studies. This could be as a result of the high $\mathrm{pH}(9.825)$ that 
could have affected the microalgae. Most microalgal systems operate best at $\mathrm{pH}$ of 7.0-8.0 (Zhao et al., 2016).

In this current study, the DO of the sewage increased gradually to $100 \%$ with the increase in experimental time from $2.23 \mathrm{mg} / \mathrm{L}$ to $5.4 \mathrm{mg} / \mathrm{L}$. Cooper and Smith (2015) assert that this increase in DO is as a result of photosynthesis where oxygen is generated as a by-product. Depletion of Vibrio cholerae populations in the sewage wastewater denotes that fewer organisms were using up the oxygen hence the increase in DO (Ajala and Alexander, 2020). Cooper and Smith (2015) explain that as the $\mathrm{pH}$ increases, the DO also increases and they attribute this increase to microalgal photosynthesis which produces oxygen molecules. Another study by Segovia-Bifarini et al. (2020) revealed that DO is affected by salinity. Increased salinity in sewage wastewater results in decreased DO because saltier water holds less oxygen. In this study, salinity decreased by $100 \%$ from 5 ppt to 0 ppt thereby conforming to findings by (Segovia-Bifarini et al., 2020).

COD gradually decreased during the experimental period by $50 \%$ from 426 to $213 \mathrm{mg} / \mathrm{L}$ due to the C. vulgaris' assimilating potential. The increased assimilating potential of organic compounds results in the decrease in COD concentration. Chlorella vulgaris is capable of utilizing both organic and inorganic carbon as an energy source and as a substrate (Segovia-Bifarini et al., 2020). Researches done by Kumar et al. (2013), Olguín (2003), and Sharma and Khan (2013) all showed that most microalgal species that include Chlorella vulgaris, Chlorella minutissima, and Scendesmus spp have high COD removal efficiencies. However, Wang et al. (2010) contend that COD removal efficiency depend on the wastewater type and range from $50.9 \%-83 \%$. The $50 \%$ decrease in COD is therefore in sync with results from other studies. COD removal efficiency can be as low as $38 \%$ as was discovered by Mohammed et al. (2014) when they cultivated C. vulgaris in textile wastewater.

BOD was reduced by $50 \%$ from $36 \mathrm{mg} / \mathrm{L}$ to $18 \mathrm{mg} / \mathrm{L}$. The reduction in BOD could be attributed to the ability by $C$. vulgaris to use up organic compounds for their metabolic processes. Chlorella vulgaris is able to efficiently utilize carbon, hence the increase in BOD consumption, (Berthold et al., 2019). Mohammed et al. (2014) used locally isolated C. vulgaris to treat wastewater and in that study, BOD and COD were reduced by $70 \%$ and $55 \%$, respectively. Findings from this research are therefore consistent with findings from researches done elsewhere. However, in other studies, higher BOD quantities have been removed using the same Chlorella vulgaris. Rothermel (2011) coupled wastewater treatment with an algal photo bioreactor and BOD was reduced by $83 \%$. Using results from their research, it can therefore be inferred that $C$. vulgaris could not further metabolise the organic compounds in the sewage without any outside influence as was the case with the photobioreactor (Rothermel, 2011).

Vibrio cholerae populations were totally eliminated within the 21 days of the study period as shown in Table 5. A study by Cole (2003) to investigate interaction of bacteria and algae revealed that algae are capable if inhibiting bacterial growth in two ways. Algae can produce a number of polyunsaturated fatty acids that have antibiotic effect. This was reiterated by Fergola et al. (2007) who explained that chlorellin is one of the compounds produced by algae to stifle growth of bacteria.
Chlorellin affects both Gram positive and Gram negative bacteria by disrupting important life processes that include respiration and cell division. Cole (2003) further posits that as the algae grow, the rate of photosynthesis also increases resulting in depletion of organic compounds and elevated $\mathrm{pH}$. The elevated $\mathrm{pH}$ alters the macro-environments and decreases the nutrient removal abilities of the bacteria. In another study by Mubashar et al. (2020) to investigate the effect of algae on coliforms and E. coli in seafood wastewater, it was observed that bacterial population were significantly reduced in 3 days. $\mathrm{Ru}$ et al. (2020) further explain that competitive interactions inhibit bacterial growth because algae outcompetes the bacteria in assimilation of limiting nutrients such as nitrogen and phosphorus. In the current study, Vibrio cholerae thrived in parametric conditions expressed in Table 1, as the nutrients decreased in quantities, the $V$. cholerae also reduced in numbers. It can be concluded that the change in physical and chemical parameters caused by $C$. vulgaris competitively excluded the Vibrio cholerae. Results from a study by Wirth et al. (2020) on microalgae-bacteria interactions in wastewater concluded that bacterial species diminish because of the high dissolved organic and inorganic removal capabilities of the microalgae. This result, therefore, strongly correlates with results from other researches globally.

\section{Description of the Prototype}

The design of the prototype follows the findings from the research and the conditions under which the findings were obtained. Therefore, the following prototype design was constituted based on (i) physico-chemical parameters and (ii) microalgae-bacteria relationship. This prototype was done at reduced settings therefore bioremediation at larger scales require the multiplier effect. The prototype is presented in the form of a flow diagram (Figure 6).

In the flow diagram, to the raw sewage distributed into the three tanks, an equal amount of $C$. vulgaris culture was added and the contents were homogenised. Extracts from each tank were taken and physico-chemical parameters were measured and recorded on weekly basis. $V$. cholerae were also enumerated. The bioremediation capacity of $C$. vulgaris resulted in the progressive reduction in colony counts of the $V$. cholerae as the experiment progressed, until such a time when no colonies were identified in the samples NB. The different colour intensities on the flow diagram from deep to light blue signify the bioremediation effect of $C$. vulgaris.

\section{CONCLUSIONS AND RECOMMENDATIONS}

Samples of raw sewage taken from home spills in Chegutu contained large quantities of Vibrio cholerae that were too many to be counted. This may explain why there has been high prevalence of cholera outbreaks in the town. The physical and chemical parameter tests carried out on the sample revealed high quantities of phosphates, nitrates, organic and inorganic compounds. Literature from past studies explains that it is these elevated quantities of pollutants that cause Vibrio cholerae to thrive in the sewage wastewater.

Chlorella vulgaris proved to be the microalgae for the bioremediation of the Vibrio cholerae in the raw sewage 


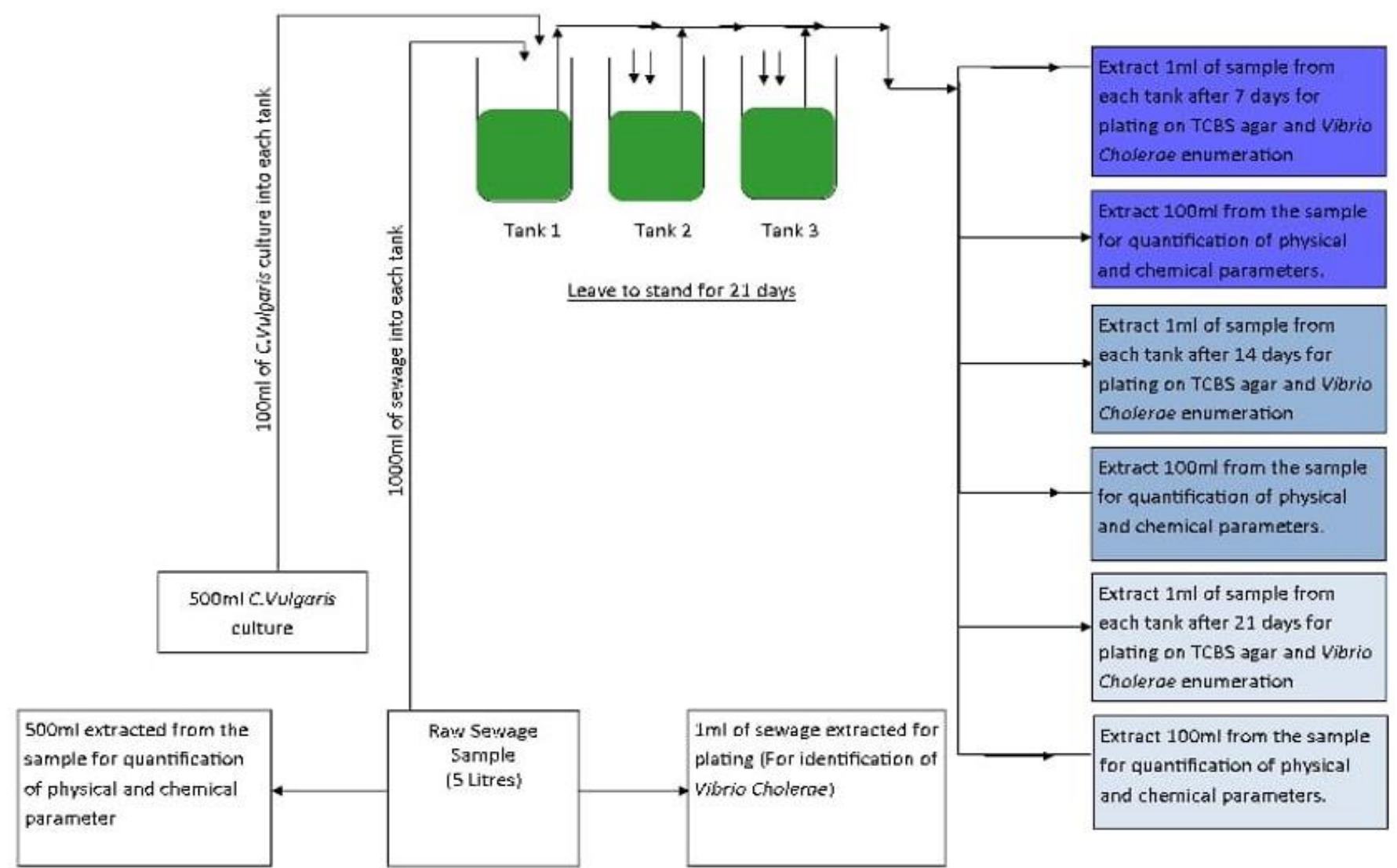

Figure 6. Prototype for the elimination of $V$. cholera from Chegutu town raw sewage

sample. The microalga's capacity to remove nutrients efficiently as explained in previous studies helped to achieve the bioremediation process. The proliferation of the microalga in the nutrient rich raw sewage helped in the elimination of the Vibrio cholerae coupled with the reduction in the physicochemical properties of the raw sewage. Indirectly this has made the sewage less polluted and hence prevents eutrophication. Whilst this method achieved the total elimination of the Vibrio cholerae, there was reduction in the level of pollutants in the sewage.

Chlorella vulgaris demonstrated that it is pollutant sequestrant therefore the decrease was due to the microalga taking up the pollutants and use them as nutrients for growth and biomass increase. The nitrates, phosphates, total dissolved and suspended solids are assimilated by the microalgal cells and used for synthesis of cell components that include phospholipids. The gradual decrease in COD and BOD denotes that the pollutants in the sample were depleting. Continued removal of these inorganic compounds by the microalga eventually leaves the wastewater fit for reuse especially in agriculture. The increases observed in $\mathrm{DO}$ and $\mathrm{pH}$ were both as a result of photosynthesis. Chlorella vulgaris had proliferated due to the nutrients in the sample resulting in increased photosynthesis rate and subsequent increase in the quantities of oxygen produced. The DO value increased because there was less Vibrio cholerae in the sample to take up the oxygen for respiration.

Depletion of pollutants, organic and inorganic compounds disrupt the natural phycosphere throwing the Vibrio cholerae in states in which they fail to assimilate the phosphates and the nitrates. The Chlorella vulgaris outcompete the Vibrio cholerae in assimilation of nutrients. This is in line with previous studies that showed that the microalga is capable of producing polyunsaturated fatty acids that exhibit antibiotic properties thereby inhibiting growth of Vibrio cholerae.

Following the outcome of the results obtained from laboratory procedures, a prototype has been designed for the bioremediation of sewage from Chegutu Municipality. Whilst the municipality has its traditional way of sewage treatment, the designed prototype could augment this by eliminating Vibrio cholerae.

The research findings paved way for the design of a prototype to eliminate Vibrio cholerae from Municipality of Chegutu sewage. The prototype could be employed to eliminate other microorganisms that cause different microbial infections in communities. These microorganisms include Salmonella spp, Shigella spp and Campylobacter spp.

The prototype produced in this current study was done at laboratory scale; however, it could be used at a larger scale using the multiplier effect. As alluded to in the introduction section of the first chapter, the town of Chegutu has experienced a couple of cholera outbreaks due to contamination of drinking water with sewage spills that are common in streets and some homesteads. The prototype could therefore be adopted to eliminate Vibrio cholerae and pollutants from these sewage spills.

The Chlorella vulgaris prototype could be used by municipalities for the treatment of sewage wastewater to halt eutrophication that can be caused by the phosphates and nitrates that may be contained in chemicals used in wastewater treatment plants. The phosphates and nitrates 
may cause algal blooms in water bodies resulting in death of fish and other aquatic organisms. Chlorella vulgaris could therefore serve dual purpose of eliminating both microorganisms and chemicals accumulated in water bodies.

Author contributions: All co-authors have involved in all stages of this study while preparing the final version. They all agree with the results and conclusions.

Funding: No external funding is received for this article.

Declaration of interest: The authors declare that they have no competing interests.

Ethics approval and consent to participate: Not applicable.

Availability of data and materials: All data generated or analyzed during this study are available for sharing when appropriate request is directed to corresponding author.

\section{REFERENCES}

Ajala, S. O. and Alexander, M. L. (2020). Assessment of Chlorella vulgaris, Scenedesmus obliquus, and Oocystis minuta for removal of sulfate, nitrate, and phosphate in wastewater. International Journal of Energy and Environmental Engineering, 11, 311-326. https://doi.org/10. 1007/s40095-019-00333-0

Baron, S., Larvor, E., Chevalier, S., Jouy, E., Kempf, I., Granier, S. A. and Lesne, J. (2017). Antimicrobial susceptibility among urban wastewater and wild shellfish isolates of non01/Non-0139 Vibrio cholerae from La Rance Estuary (Brittany, France). Frontiers in Microbiology, 8, 1637. https://doi.org/10.3389/fmicb.2017.01637

Basika, E., Banadda, N. and Kiggundu, N. (2020). A review of usage of wastewater sludge and its environmental impacts. MOJ Ecology \& Environmental Sciences, 5(6), 280-284. https://doi.org/10.15406/mojes.2020.05.00205

Berthold, D. E., Shetty, K. G., Jayachandran, K., Laughinghouse IV, H. D. and Gantar, M. (2019). Enhancing algal biomass and lipid production through bacterial co-culture. Biomass and Bioenergy, 122, 280-289. https://doi.org/10.1016/ j.biombioe.2019.01.033

Bharati, K. and Ganguly, N. K. (2011). Cholera toxin: A paradigm of a multifunctional protein. The Indian Journal of Medical Research, 133(2), 179-187.

Bloomfield, J. and Fisher, M. J. (2019). Quantitative research design. Journal of the Australasian Rehabilitation Nurses Association, 22(2), 27-30. https://doi.org/10.33235/jarna. 22.2.27-30

Cartwright, E. J., Patel, M. K., Mbopi-Keou, F. X., Ayers, T., Haenke, B., Wagenaar, B. H., Mintz, E. and Quick, R. (2013). Recurrent epidemic cholera with high mortality in Cameroon: Persistent challenges 40 years into the seventh pandemic. Epidemiology \& Infection, 141(10), 2083-2093. https://doi.org/10.1017/S0950268812002932

Chegutu Municipal Newsletter. (2018). Chegutu Municipality. Available at: http://www.chegutumunicipality.co.zw/ documents/municipalnewslettervolume3.pdf
Chiu, S.-Y., Kao, C.-Y., Chen, T.-Y., Chang, Y.-B., Kuo, C.-M. and Lin, C.-S. (2015). Cultivation of microalgal Chlorella for biomass and lipid production using wastewater as nutrient resource. Bioresource Technology, 184, 179-189. https://doi.org/10.1016/j.biortech.2014.11.080

Cooper, M. B. and Smith, A. G. (2015). Exploring mutualistic interactions between microalgae and bacteria in the omics age. Current Opinion in Plant Biology, 26, 147-153. https://doi.org/10.1016/j.pbi.2015.07.003

Dasgupta, C. N., Toppo, K., Nayaka, S. and Singh, A. K. (2019). Bioremediation of municipal sewage using potential microalgae. In S. K. Gupta and F. Bux (Eds.), Application of microalgae in wastewater treatment (pp. 121-144). Springer. https://doi.org/10.1007/978-3-030-13913-1_7

Demirbas, A., Edris, G. and Alalayah, W. M. (2017). Sludge production from municipal wastewater treatment in sewage treatment plant. Energy Sources, Part A: Recovery, Utilization, and Environmental Effects, 39(10), 999-1006. https://doi.org/10.1080/15567036.2017.1283551

Dumontet, S., Scopa, A., Kerje, S. and Krovacek, K., 2001. The importance of pathogenic organisms in sewage and sewage sludge. Journal of the Air \& Waste Management Association, 51(6), 848-860. https://doi.org/10.1080/ 10473289.2001.10464313

Fergola, P., Cerasuolo, M., Pollio, A., Pinto, G. and Dellagreca, M. (2007). Allelopathy and competition between Chlorella vulgaris and Pseudokirchneriella subcapitata: Experiments and mathematical model. Ecological Modelling, 208(2-4), 205-214. https://doi.org/10.1016/j.ecolmodel.2007.05.024

Ferreira, A. and Gouveia, L. (2020). Microalgal biorefineries. In E. Jacob-Lopes, L. G. R. Mérida, M. I. Queiroz and L. Q. Zepka (Eds.), Handbook of microalgae-based processes and products (pp. 771-798). Elsevier. https://doi.org/10.1016/ B978-0-12-818536-0.00028-2

Garcha, S., Verma, N. and Brar, S. K. (2016). Isolation, characterization and identification of microorganisms from unorganized dairy sector wastewater and sludge samples and evaluation of their biodegradability. Water Resources and Industry, 16, 19-28. https://doi.org/10.1016/ j.wri.2016.10.002

Goertzen, M. J. (2017). Introduction to quantitative research and data. Library Technology Reports, 53(4), 12-18.

Gonçalves, A. L., Pires, J. C. M. and Simões, M. (2017). A review on the use of microalgal consortia for wastewater treatment. Algal Research, 24 (Part B), 403-415. https://doi.org/10.1016/j.algal.2016.11.008

Huq, A. and Colwell, R. R. (1996). A microbiological paradox: viable but nonculturable bacteria with special reference to Vibrio cholerae. Journal of Food Protection, 59(1), 96-101. https://doi.org/10.4315/0362-028X-59.1.96

Huq, A., Sack, R. B., Nizam, A., Longini, I. M., Nair, G. B., Ali, A., Morris Jr., J. G., Khan, M. H., Siddique, A. K., Yunus, M. and Albert, M. J. (2005). Critical factors influencing the occurrence of Vibrio cholerae in the environment of Bangladesh. Applied and Environmental Microbiology, 71(8), 4645-4654. https://doi.org/10.1128/AEM.71.8.4645-4654. 2005 
Jena, N. and Nyakudya, M. (2018, January 20). Cholera hits Zimbabwe, 4 die in Chegutu. NewsDay.Available at: https://www.newsday.co.zw/2018/01/cholera-hits-zim-4die-chegutu

Kumar, B. R., Prasad, M. L., Srinivasarao, D. and Sambasiva Rao, K. R. S. (2013). Bioremediation of sewage using specific consortium of microorganisms. International Journal of Research in Applied, Natural and Social Sciences, 1(6), 15-26.

Kumar, R. and Kundu, S. (2020). Microbial bioremediation and biodegradation of hydrocarbons, heavy metals, and radioactive wastes in solids and wastewaters. In M. Shah (Ed.), Microbial Bioremediation \& Biodegradation (pp. 95112). Springer. https://doi.org/10.1007/978-981-15-1812644

Maliki, M., Adedokun, R. A., Afehomo, E. and Ikhide, O. O. (2020). Comparative evaluation of the physicochemical properties of different agricultural wastewaters in Edo State, Nigeria. Journal of Chemical Society of Nigeria, 45(3), 477-485.

Mengel, M. A., Delrieu, I., Heyerdahl, L. and Gessner, B. D. (2014). Cholera outbreaks in Africa. Cholera Outbreaks, 379, 117-144. https://doi.org/10.1007/82_2014_369

Mohammed, M. A., Shitu, A., Tadda, M. A. and Ngabura, M. (2014). Utilization of various agricultural waste materials in the treatment of Industrial wastewater containing Heavy metals: A review. International Research Journal of Environmental Sciences, 3(3), 62-71.

Mora-Ravelo, S., Alarcon, A., Rocandio-Rodriguez, M. and Vanoye-Eligio, V. (2017). Bioremediation of wastewater for reutilization in agricultural systems: A review. Applied Ecology and Environmental Research, 15(1), 33-50. https://doi.org/10.15666/aeer/1501_033050

Mubashar, M., Naveed, M., Mustafa, A., Ashraf, S., Shehzad Baig, K., Alamri, S., Siddiqui, M. H., Zabochnicka-Świątek, M., Szota, M. and Kalaji, H. M. (2020). Experimental investigation of Chlorella vulgaris and Enterobacter sp. MN17 for decolorization and removal of heavy metals from textile wastewater. Water, 12(11), 3034. https://doi.org/10. 3390/w12113034

Mulamattathil, S. G., Bezuidenhout, C., Mbewe, M. and Ateba, C. N. (2014). Isolation of environmental bacteria from surface and drinking water in Mafikeng, South Africa, and characterization using their antibiotic resistance profiles. Journal of Pathogens, 2014, 371208. https://doi.org/10.1155/2014/371208

Nathanson, J. A. and Ambulkar, A. (2018). Wastewater treatment. Available at: https:/www.britannica.com/ technology/wastewater-treatment/Primary-treatment\# ref593251

Nongogo, V. and Okoh, A. I. (2014). Occurrence of Vibrio pathotypes in the final effluents of five wastewater treatment plants in Amathole and Chris Hani District Municipalities in South Africa. International Journal of Environmental Research and Public Health, 11(8), 77557766. https://doi.org/10.3390/ijerph110807755
Nyamukondiwa, W. (2018). Chegutu cholera cases up. The Herald. Available at: https://www.herald.co.zw/chegutucholera-cases-up/\#: :text=THE\%20number\%20of\%20 suspected\%20cholera,died\%20of\%20cholera\%20in\%20Ch egutu (Accessed 22 January 2018).

Okeyo, A. N., Nontongana, N., Fadare, T. O. and Okoh, A. I. (2018). Vibrio species in wastewater final effluents and receiving watershed in South Africa: Implications for public health. International Journal of Environmental Research and Public Health, 15(6), 1266. https://doi.org/10. 3390/ijerph15061266

Olguín, E. J. (2003). Phycoremediation: Key issues for costeffective nutrient removal processes. Biotechnology Advances, 22(1-2), 81-91. https://doi.org/10.1016/S07349750(03)00130-7

Osunla, C. A. and Okoh, A. I. (2017). Vibrio pathogens: A public health concern in rural water resources in sub-Saharan Africa. International Journal of Environmental Research and Public Health, 14(10), 1188. https://doi.org/10.3390/ ijerph14101188

Otondo, A., Kokabian, B., Stuart-Dahl, S. and Gude, V. G. (2018). Energetic evaluation of wastewater treatment using microalgae, Chlorella vulgaris. Journal of Environmental Chemical Engineering, 6(2), 3213-3222. https://doi.org/ 10.1016/j.jece.2018.04.064

Pilon-Smits, E. (2005). Phytoremediation. Annual Review of Plant Biology, 56, 15-39. https://doi.org/10.1146/annurev. arplant.56.032604.144214

Prasad, M. N. V., de Campos Favas, P. J., Vithanage, M. and Mohan, S. V. (eds.). (2019). Industrial and municipal sludge: Emerging concerns and scope for resource recovery. Butterworth-Heinemann.

Robinson, R. K. (2014). Encyclopedia of food microbiology. Academic Press.

Rothermel, M. C. (2011). Coupling the wastewater treatment process with an algal photobioreactor for nutrient removal and renewable resource production [Doctoral dissertation, University of Pittsburgh].

Ru, I. T. K., Sung, Y. Y., Jusoh, M., Wahid, M. E. A. and Nagappan, T. (2020). Chlorella vulgaris: A perspective on its potential for combining high biomass with high value bioproducts. Applied Phycology, 1(1), 2-11. https://doi.org/ 10.1080/26388081.2020.1715256

Sabuda, M. C., Rosenfeld, C. E., DeJournett, T. D., Schroeder, K., Wuolo-Journey, K. and Santelli, C. M. (2020). Fungal bioremediation of selenium-contaminated industrial and municipal wastewaters. Frontiers in Microbiology, 11, 2105. https://doi.org/10.3389/fmicb.2020.02105

Salgueiro, J. L., Perez, L., Maceiras, R., Sanchez, A. and Cancela, A. (2016). Bioremediation of wastewater using Chlorella vulgaris microalgae: Phosphorus and organic matter. International Journal of Environmental Research, 10(3), 465-470.

Segovia Bifarini, M. A., Žitnik, M., Griessler Bulc, T. and Krivograd Klemenčič, A. (2020). Treatment and re-use of raw blackwater by Chlorella vulgaris-based system. Water, 12(10), 2660. https://doi.org/10.3390/w12102660 
Sero, E. T., Siziba, N., Bunhu, T. and Shoko, R. (2021). Isolation and screening of microalgal species, native to Zimbabwe, with potential use in biodiesel production. All Life, 14(1), 256-264. https://doi.org/10.1080/26895293.2021.1911862

Shaffer, N., do Santos, E. S., Andreason, P. A. and Farmer III, J. J. (1989). Rapid laboratory diagnosis of cholera in the field. Transactions of the Royal Society of Tropical Medicine and Hygiene, 83(1), 119-120. https://doi.org/10.1016/00359203(89)90733-5

Shahid, A., Malik, S., Zhu, H., Xu, J., Nawaz, M. Z., Nawaz, S., Alam, M. A. and Mehmood, M. A. (2020). Cultivating microalgae in wastewater for biomass production, pollutant removal, and atmospheric carbon mitigation; a review. Science of the Total Environment, 704, 135303. https://doi.org/10.1016/j.scitotenv.2019.135303

Sharma, G. K. and Khan, S. A. (2013). Bioremediation of sewage wastewater using selective algae for manure production. International Journal of Environmental Engineering and Management, 4(6), 573-580.

Shields, P. and Cathcart, L. (2010). Oxidase test protocol. Available at: https://asm.org/getattachment/00ce86398e76-4acb-8591-0f7b22a347c6/oxidase-test-protocol3229.pdf

Sirisha, T., Aleem Bash, P. and Kavitha, B. (2017). Isolation and characterization of pathogenic bacteria from Kundu river water of Nandyal, Kurnool, Andhra Pradesh, India. Journal of Applied Sciences, 17(9), 475-481. https://doi.org/10. 3923/jas.2017.475.481

Taziki, M., Ahmadzadeh, H., Murry, M. A. and Lyon, S. R. (2015). Nitrate and nitrite removal from wastewater using algae. Current Biotechnology, 4(4), 426-440. https://doi.org/ $10.2174 / 2211550104666150828193607$

Toze, S. (1997). Microbial pathogens in wastewater: Literature review for urban water systems multi-divisional research program. Available at: https://www.worldcat.org/title/ microbial-pathogens-in-wastewater-literature-reviewfor-urban-water-systems-multi-divisional-researchprogram/oclc/223756003

UNICEF. (2018). Zimbabwe: Cholera outbreak report. UNICEF Zimbabwe. Available at: https://www.unicef.org/media/ 76176/file/Zimbabwe-Cholera-SitRep-23-Nov-2018.pdf
Wang, H., Wang, T., Zhang, B., Li, F., Toure, B., Omosa, I. B., Chiramba, T., Abdel-Monem, M. and Pradhan, M. (2014). Water and wastewater treatment in Africa-current practices and challenges. CLEAN-Soil, Air, Water, 42(8), 1029-1035. https://doi.org/10.1002/clen.201300208

Wang, L., Min, M., Li, Y., Chen, P., Chen, Y., Liu, Y., Wang, Y. and Ruan, R. (2010). Cultivation of green algae Chlorella sp. in different wastewaters from municipal wastewater treatment plant. Applied Biochemistry and Biotechnology, 162(4), 1174-1186. https://doi.org/10.1007/s12010-0098866-7

Winstead, A., Strysko, J., Relan, P., Conners, E. E., Martinsen, A. L., Lopez, V., Arons, M., Masunda, K. P., Mukeredzi, I., Manyara, J. and Duri, C. (2020). Notes from the field: Cholera outbreak-Zimbabwe, September 2018-March 2019. Morbidity and Mortality Weekly Report, 69(17), 527. https://doi.org/10.15585/mmwr.mm6917a3

Wirth, R., Pap, B., Böjti, T., Lakatos, G., Bagi, Z., Shetty, P., Kovács, K. L. and Maróti, G. (2020). Chlorella vulgaris and its phycosphere in wastewater: Microalgae-bacteria interactions during nutrient removal. Frontiers in Bioengineering and Biotechnology, 8, 1108. https://doi.org/ 10.3389/fbioe.2020.557572

World Health Organization. (2018). Cholera. Weekly Epidemiological Record 2019, 48(94), 567-580.

World Health Organization. (2019). Cholera. Weekly Epidemiological Record 2020, 37(95), 441-448.

Xin, L., Hong-Ying, H., Ke, G. and Ying-Xue, S. (2010). Effects of different nitrogen and phosphorus concentrations on the growth, nutrient uptake, and lipid accumulation of a freshwater microalga Scenedesmus sp. Bioresource Technology, 101(14), 5494-5500. https://doi.org/10.1016/ j.biortech.2010.02.016

Zhao, B., Zhang, Y., Xiong, K., Zhang, Z., Hao, X. and Liu, T. (2011). Effect of cultivation mode on microalgal growth and $\mathrm{CO} 2$ fixation. Chemical Engineering Research and Design, 89(9), 1758-1762. https://doi.org/10.1016/j.cherd. 2011.02.018

Zhao, Y., Ge, Z., Lui, H. and Sun, S. (2016). Ability of different microalgae species in synthetic high-strength wastewater treatment and potential lipid production. Journal of Chemical Technology \& Biotechnology, 91(11), 2888-2895. https://doi.org/10.1002/jctb.4905 